\title{
Evidence of bottom-up control of diet driven by top-down processes in a declining harbor seal Phoca vitulina richardsi population
}

\author{
Jason K. Herreman ${ }^{1, *}$, Gail M. Blundell ${ }^{2}$, Merav Ben-David ${ }^{1}$ \\ ${ }^{1}$ Department of Zoology and Physiology, University of Wyoming, 1000 East University Avenue, Laramie, \\ Wyoming 82071, USA
}

${ }^{2}$ Alaska Department of Fish and Game, Division of Wildlife Conservation, PO Box 110024, Juneau, Alaska 99811-0024, USA

\begin{abstract}
Two mechanisms of population control dominate most biological systems: bottom-up and top-down regulation. It is possible, however, that top-down mediation may lead to bottom-up control of a population if predators simultaneously compete for the same prey. Harbor seal Phoca vitulina richardsi populations in Glacier Bay (GB) and Prince William Sound (PWS), Alaska, have declined drastically since the 1970s, with PWS recently stabilizing and GB continuing to decline. Hypotheses for the declines include both bottom-up and top-down processes. We hypothesized that increased competition and predation risk are causing harbor seals in GB to forage on lower quality prey. We combined analyses of prey remains in scat and stable carbon and nitrogen isotope ratios in blood and hair to compare seal diets in these areas. Seal diets in GB and PWS varied spatially and temporally due to changes in resource availability and sexual segregation. Adults showed clear divergence in diet during specific times of the year in both areas. Sexual segregation of diet in GB was most prevalent during spring and fall, while in PWS segregation was greatest during late summer. Diet of seals in PWS showed annual variation not found in GB, likely following prey cycles. In GB during summer, all seals switched to a diet with a lower fat content, including more intertidal/ demersal species such as rockfish and sculpin. This switch coincided with an increase in competitors and predators entering GB. The change in diet, combined with higher emigration of harbor seals out of $\mathrm{GB}$, suggest that increased competition and risk of predation may contribute to overall population declines.
\end{abstract}

KEY WORDS: Population decline - Phoca vitulina richardsi · Feces · Pinnipeds · Prey remains · Sexual segregation $\cdot$ Stable isotopes

Resale or republication not permitted without written consent of the publisher

\section{INTRODUCTION}

Ecologists generally consider 2 types of population control: bottom-up and top-down regulation. Topdown regulation occurs when a predator directly limits the number of prey individuals in a population (Power 1992). Top-down regulation, as suggested by Springer et al. (2003), has become one of the leading hypotheses for marine mammal declines throughout the North Pacific Ocean. According to this hypothesis, the sequential declines of great whales under the whaling pressure of the late 1800s were followed by increased predation by killer whales Orcinus orca on Steller sea lions Eumetopias jubatus, harbor seals Phoca vitulina and, more recently, sea otters Enhydra lutris (Estes et al. 2006). This explanation of harbor seal population crashes, along with other marine mammals, has been highly controversial (Trites et al. 2007a, Wade et al. 2007). The alternative hypothesis for the decline of marine mammal populations involves bottom-up mediation through regime shifts and over-harvest of fisheries (Trites et al. 1997, Francis et al. 1998, Rosen \& Trites 2000, Trites \& Donnelly 2003, Trites et al. 2007b). Bottom-up population control usually occurs through nutritional stress caused by limited prey availability or poor diet quality (Power 1992). This 'junk food' hypo- 
thesis, however, has been challenged recently because gadids, which are of low nutritional value and supposedly increased with the regime shift, make up large portions of sea lion diets in areas where numbers of sea lions are increasing, and field studies show no evidence of nutritional stress in species feeding largely on gadids (Fritz \& Hinckley 2005).

This dichotomous view of population regulation may be too simplistic for marine ecosystems, where multiple predators of varying sizes (e.g. seals, sea lions, and whales) can simultaneously compete for the same food base, as well as prey on each other (i.e. larger predators prey on smaller predators; Estes et al. 2006). This creates 3 pathways for top predators to regulate the populations of smaller predators. First, top predators can directly feed on the smaller ones. Second, top predators can out-compete smaller predators by depleting the common food base. Finally, top predators can displace smaller predators from high-quality forage (e.g. smaller predators minimize predation risk by foraging elsewhere on lower quality prey), causing nutritional stress in the latter (Stiling 1999). Each and all of these mechanisms could lead to population declines in smaller, less competitive predators.

Harbor seals Phoca vitulina richardsi in Prince William Sound (PWS), Alaska, have declined by $>65 \%$ since the 1970s (Frost et al. 1999, Boveng et al. 2003, Jemison et al. 2006), but the population has recently shown signs of stabilizing (Alaska Department of Fish and Game, ADF\&G, unpubl. data). Since 1992, a decline of similar magnitude has been documented in Glacier Bay (GB) National Park, occurring at the precipitous rate of $14.5 \%$ per year (Mathews \& Pendleton 2006). The causes for these declines are unclear. Simplistic bottom-up and top-down hypotheses for explaining these declines may be unsatisfactory because of the unique conditions that exist in GB. Primary productivity in GB is high (Hooge \& Hooge 2002), suggesting high food availability for seals. Commercial fishing has also been nearly eliminated from GB since the mid-1980s and currently occurs only on a limited scale (Catton 1995). Further, National Park Service regulations do not permit subsistence harvest of seals within $\mathrm{GB}$, and motorized vessels are restricted from entering birthing areas during pupping and lactation periods (May and June), reducing stress from disturbance. Concurrently, however, other marine mammals that use the same food base, including several seal predators, have been steadily increasing in GB while remaining relatively constant in PWS (Angliss \& Outlaw 2007). Steller sea lions increased by $485 \%$ in GB (Mathews \& Pendleton 2006, Gelatt et al. 2007), humpback whales Megaptera novaeangliae by $55 \%$ (Mathews \& Pendleton 2006, Neilson \& Gabriele 2006), and killer whales have also increased significantly (Angliss
\& Outlaw 2007, Matkin et al. 2007). Thus, harbor seals in GB have likely experienced heightened competition and predation risk in recent years.

Previous studies in both terrestrial and aquatic habitats have shown that animals may change their foraging habits when encountering high competition or risk of predation. Under such conditions, animals will often forego areas with high-quality forage and consume less nutritious foods (Werner et al. 1983, Holbrook \& Schmitt 1988, Werner \& Hall 1988, Ibrahim \& Huntingford 1989). Stewart et al. (2003) observed that mule deer Odocoileus hemionus in Oregon were displaced by North American elk Cervus elaphus and free-ranging cattle Bos taurus and, as a result, foraged on a higher diversity of lower quality plants in xeric habitats. Alternatively, under heightened competition or predation risk, sexual and age segregation of habitat use and diet can occur (Werner et al. 1983, Corti \& Shackleton 2002). Bleich et al. (1997) documented segregation of male and female mountain sheep Ovis canadensis nelsoni, with females selecting for areas with lower predator densities. This sexual segregation resulted in a lower quality diet for females (Bleich et al. 1997). Page et al. (2005) documented differences in diet composition and quality among male and female New Zealand and Australian fur seals Arctocephalus forsteri and A. pusillus doriferus. In that system, sexual dietary segregation resulted from heightened interspecific competition.

To investigate whether recent increases in competitors and predators in GB can be implicated in seal declines, we compared the diet of seals in GB and PWS. We hypothesized that seal diets in GB will be more variable, include lower quality dietary items, and differ between age groups and sexes under conditions of heightened competition and/or increased risk of predation. We also compared the diets of animals found on ice and at terrestrial haul-out sites to see if animals that use a particular habitat may be consuming lower quality forage, which could affect survival and recruitment in that portion of the population. Such a difference could be important, as the majority of seals in GB can be found hauled out on icebergs in glacial fjords during pupping and molting seasons (Mathews \& Pendleton 2006).

\section{MATERIALS AND METHODS}

To determine seal diets and evaluate differences between sexes, among age groups, and between animals that use different habitat types, we used 2 approaches: (1) we identified hard prey remains in scats for which gender was determined using DNA analysis, and (2) we estimated diet through stable car- 


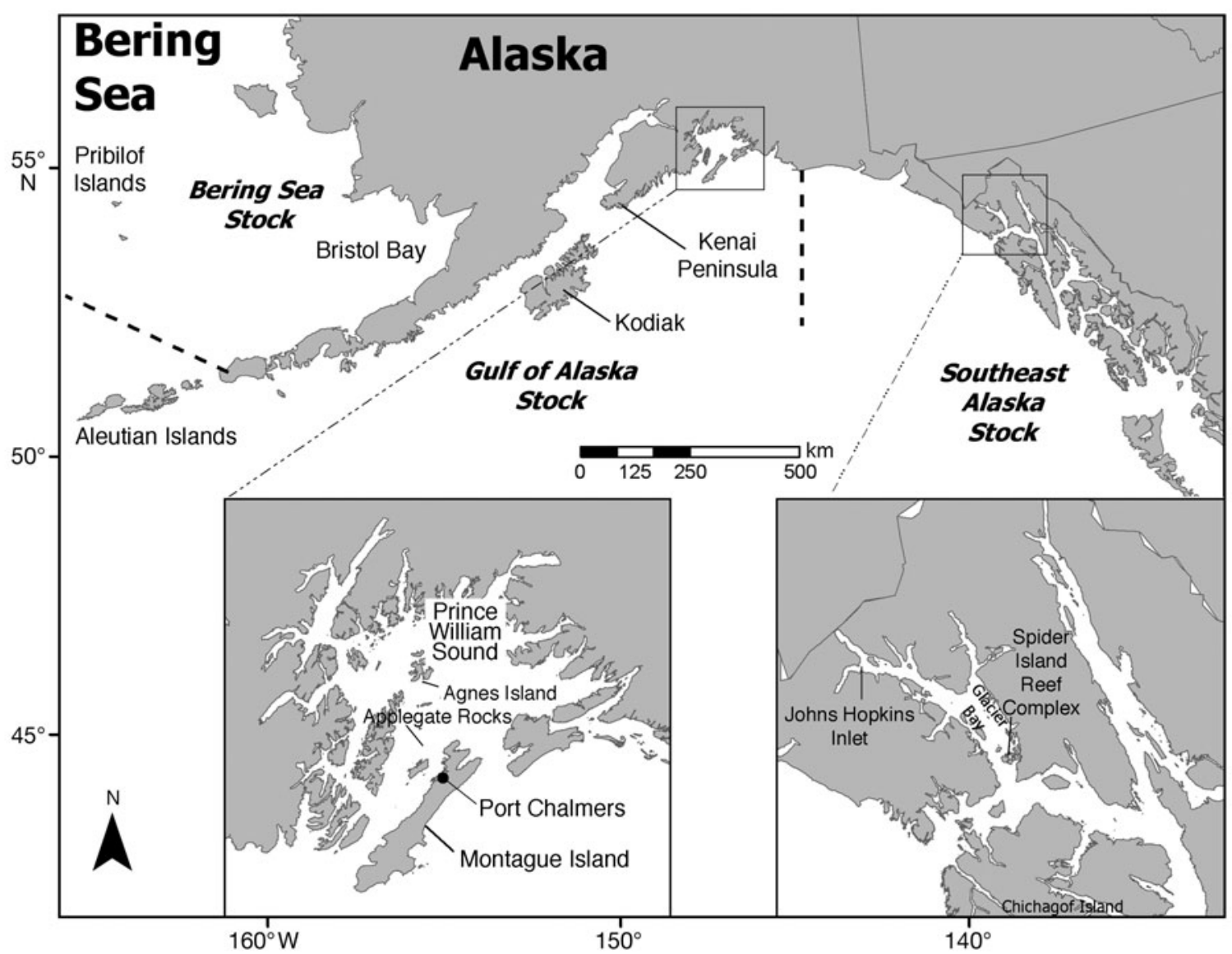

Fig. 1. Study areas (Prince William Sound and Glacier Bay) and current delineations of stock boundaries (thick dashed lines) of harbor seals in Alaska, as defined by the National Marine Fisheries Service. Fig. 1 produced by S. Albeke

bon and nitrogen isotope analyses of blood and hair samples collected from live-captured animals. Previous studies have shown that $\delta^{13} \mathrm{C}$ levels of fishes differ between pelagic and intertidal/subtidal zones in the same region (Blundell et al. 2002). Thus, $\delta^{13} \mathrm{C}$ levels can be used to compare foraging habits of seals within regions and between different seasons. To compare the results from the 2 approaches, we converted the isotope data to an index of relative contribution using linear mixing models (Ben David et al. 1997, Phillips \& Gregg 2003).

Sample collection. We collected tissue and fecal samples under National Marine Fisheries Service (NMFS) Permit Nos. 358-1585 and 358-1787 from live-captured harbor seals and from haul-outs in PWS and GB, Alaska, USA, between 2003 and 2006 (Fig. 1). Seals in PWS were captured solely at terrestrial sites (the nearest glacial fjord, ca. $55 \mathrm{~km}$ away). Conversely, seals in GB were captured at both ice and terrestrial sites with an approximate distance of $85 \mathrm{~km}$ between habitat types. We captured seals from terrestrial haulouts using multifilament seine nets and from iceberg haul-outs using monofilament gillnets. Terrestrial haul-outs sampled in GB (central location of study area: $58^{\circ} 31^{\prime} 17.36^{\prime \prime} \mathrm{N}, 1^{\circ} 55^{\circ} 52.177^{\prime \prime} \mathrm{W}$ ) included Spider Island Reef Complex, Kidney Island, Secret Bay, Geiki Rock, Leland and Boulder reefs, and a tidal passage near the mouth of the Bartlett River. All seals captured on ice floes were from Johns Hopkins Inlet. Areas sampled in PWS (central location of study area: $60^{\circ} 21^{\prime} 31.269 " \mathrm{~N}, 147^{\circ} 23^{\prime} 13.344^{\prime \prime} \mathrm{W}$ ) included Applegate Rocks, Big Smith Island, Channel Island, Agnes Island, Port Chalmers, Seal Island, and Little Green Island. A representative sample of age classes and sexes for a total of 291 animals from GB and 236 animals from PWS were included in the present study (Table 1).

We weighed all captured animals to the nearest $0.1 \mathrm{~kg}$ and then injected them intravenously with $0.25 \mathrm{mg} \mathrm{kg}^{-1}$ body weight of valium (Hospira). We measured standard length, curvilinear length, axial girth, maximum girth, and hip girth to the nearest centimetre. Age of individual seals was estimated based on these morphometric measurements (Blundell $\&$ Pendleton 2008). Morphometric ages were determined separately for male and female seals. We classi- 
Table 1. Phoca vitulina richardsi. Number of adult males (AM), adult females (AF), sub-adult males (SAM) and sub-adult females $(\mathrm{SAF})$, and juvenile males and females (JM, JF, respectively) captured in Prince William Sound (PWS) and Glacier Bay (GB), Alaska, 2003 to 2006

\begin{tabular}{|c|c|c|c|c|c|c|c|c|c|c|c|c|}
\hline & \multicolumn{6}{|c|}{ - PWS - } & \multirow[b]{2}{*}{$\mathrm{AM}$} & \multirow[b]{2}{*}{$\mathrm{AF}$} & \multirow{2}{*}{$\begin{array}{c}\text { SAM } \\
\text { GH }\end{array}$} & \multirow[b]{2}{*}{ SAF } & \multirow[b]{2}{*}{$\mathrm{JM}$} & \multirow[b]{2}{*}{$\mathrm{JF}$} \\
\hline & AM & $\mathrm{AF}$ & SAM & SAF & $\mathrm{JM}$ & JF & & & & & & \\
\hline Blood & 22 & 33 & 23 & 28 & 41 & 40 & 50 & 27 & 18 & 24 & 74 & 72 \\
\hline Hair & 38 & 33 & 33 & 31 & 49 & 39 & 51 & 26 & 19 & 28 & 74 & 65 \\
\hline
\end{tabular}

fied all seals older than 3 yr as adults, seals between 1 and 3 yr as sub-adults, and all seals younger than 1 yr as juveniles. Although some seals just over 3 yr old may not have reached sexual maturity (Lydersen \& Kovacs 2005), they would have achieved the majority of their body size and should have been foraging similar to older individuals.

We drew blood from the epidural vein. Blood was immediately centrifuged at $1207 \times g$, and blood cells and serum were separated. Hair was collected by shaving a $6 \times 6 \mathrm{~cm}$ area between the lower portion of the spinal column and the right femur. All tissue samples were frozen at $-18^{\circ} \mathrm{C}$ and stored at that temperature until they were prepared for analysis in the laboratory.

Feces were collected from terrestrial haul-out sites opportunistically throughout the study and stored suspended in 200-proof ethyl alcohol. Fecal collection was attempted at ice haul-outs but was unsuccessful because feces melted into the ice or were lost as icebergs rolled and moved. Fecal samples were refrigerated at $4^{\circ} \mathrm{C}$ until sieving and DNA extraction. In all, 77 fecal samples were collected in PWS and 270 in GB.

Sex determination of feces. First, we sieved each fecal sample through a $1.4 \mathrm{~mm}$ sieve (USA Standard Test Sieve No.14, Newark Wire Cloth Company) to remove prey remains, beach material, and parasites. Prey remains were then cleaned, dried, and saved for later analyses. Once sieved, DNA was extracted from all fecal samples using a Qiagen QiAamp DNA Stool Mini Kit (QIAGEN).

To establish that the samples contained seal DNA, we first screened them with 6 microsatellite DNA primers (Herreman 2007). The samples that yielded seal DNA were then amplified using an SRY primer adopted from Richard et al. (1994). A fluorescently dyed M13 tail (CACGACGTTGTAAAACGAC) was added to the forward primer sequence to allow pooling with other primers during electrophoresis (BoutinGanache et al. 2001). Amplifications were conducted using a PTC-200 Peltier Thermal Cycler (MJ Research); cocktails and programs are described in detail in Herreman (2007). SRY amplifications were conducted by a female lab technician to prevent contamination and misclassification of the sex of the samples (Reed et al. 1997). To validate consistent sexing of feces, matched blood and fecal samples from 6 captive harbor seals (obtained from animals at the Alaska SeaLife Center, Seward) were analyzed. These samples were then used in all reactions as positive controls. Successful PCR reactions were resolved on an ABI 3130xI Automated Sequencer (Applied Biosystems) with a formamide-Liz ladder as an internal size standard in each lane. Products were analyzed using ABI GeneMapper, version 4.

To obtain a consensus genotype, each sample was analyzed at least 3 times, increasing the amount of DNA added in each run for samples that did not produce a band. If, after 3 to 7 runs, a band was produced at $165 \mathrm{bp}$ at least twice, the individual was typed as male. Feces were typed as originating from females only if a band was never produced at $165 \mathrm{bp}$ during any PCR reaction. Any sample producing a band at $165 \mathrm{bp}$ only once after 7 runs was classified as being of indeterminable sex and excluded from further analyses.

Identification of prey remains. For samples that were successfully sexed with the SRY gene, we submitted sieved prey remains to a laboratory specializing in the identification of marine organisms (Pacific IDentifications). Not all fecal samples collected contained hard prey remains. A total of 43 samples from PWS and 55 from GB were sent for analysis of prey-remains. All prey remains, except cephalopods and polychaetes, were identified to the level of species or genus. In many cases, single scats contained more than one prey item. For the sake of comparing the diets of males and females in the 2 different areas, we treated each occurrence of a prey item as an independent observation. Prey remains analyses have a tendency to underestimate highly digestible prey and to overestimate prey of low digestibility. Therefore, we corrected our estimates using correction factors developed by Murie \& Lavigne (1986), Harvey (1989), and Tollit et al. (1997).

Stable isotope ratios. Ratios of carbon and nitrogen stable isotopes in blood cells likely reflect nutrients assimilated by the animal in the 3 to 4 mo preceding collection (Hilderbrand et al. 1996). In contrast, the same ratios in hair samples reflect the diet of the animal during molt. Because of logistical constraints, we were unable to capture seals in GB and PWS simultaneously. We captured seals in GB in spring (April to 
May) and fall (September to October). In PWS, we captured seals in early spring (April), summer (June to July), and winter (February). Thus, comparing results from blood samples that we collected at different times in these 2 areas would require knowledge of prey availability and a detailed chronology of seal lifehistory patterns during the period in which samples were collected (e.g. pupping and mating). Hair samples, on the other hand, represent the same time period, as seals in both areas molt and grow new hair at approximately the same time, in late summer (July to September; Daniel et al. 2003).

We dried blood samples at 60 to $70^{\circ} \mathrm{C}$ for $48 \mathrm{~h}$. After drying, samples were ground and homogenized using a Retsch MM200 ball mill (Glenn Mills). Hair samples were washed with 200-proof ethyl alcohol, rinsed in distilled water and stored at room temperature. To homogenize hair samples, we clipped them into small sections $<1 \mathrm{~mm}$ in length. Samples were then sent to the University of Wyoming Stable Isotope Facility and analyzed for $\delta^{13} \mathrm{C}$ and $\delta^{15} \mathrm{~N}$ using a Finnigan Delta ${ }^{+\mathrm{XP}}$ continuous flow inlet Stable Isotope Ratio Mass Spectrometer (Finnigan Instruments). Each sample was analyzed in duplicate, and results were accepted only if the variance between samples did not exceed that of the peptone $\left(\delta^{13} \mathrm{C}_{\mathrm{std}}=-15.17\right.$ and $\left.\delta^{15} \mathrm{~N}_{\mathrm{std}}=5.48\right)$, EDTA $\left(\delta^{13} \mathrm{C}_{\text {std }}=-31.17\right.$ and $\left.\delta^{15} \mathrm{~N}_{\text {std }}=0.24\right)$, glycine $\left(\delta^{13} \mathrm{C}_{\text {std }}=\right.$ -30.63 and $\left.\delta^{15} \mathrm{~N}_{\text {std }}=0.70\right)$, or acetil $\left(\delta^{13} C_{\text {std }}=-30.07\right.$ and $\left.\delta^{15} \mathrm{~N}_{\text {std }}=0.34\right)$ standards, and machine linearity did not deviate from 0.99 .

Data analyses. Prey remains: To compare prey diversity of male and female seals from GB and PWS, we calculated the Shannon-Wiener diversity index (Zar 1999). We used $90 \%$ confidence intervals (Jenkins et al. 1979), calculated from the binomial distribution (Zar 1999), to compare richness of prey of males and females in GB and PWS.

Stable isotope analyses: We employed multivariate analyses of variance (MANOVA; Johnson \& Wichern 1988) to detect differences in the diets of seals as manifested by their $\delta^{13} \mathrm{C}$ and $\delta^{15} \mathrm{~N}$ values, with season, year, sex, age, area, and habitat as independent variables. In order to compare our results from analyses of prey remains with estimates of dietary assimilation from stable isotopes, we converted isotopic tissue values to relative contribution of diet using a dual-isotope, multiplesource linear mixing model with the program ISOSOURCE (Phillips \& Gregg 2003). We also employed a Bayesian multisampling statistical model (SISUS: Stable Isotope Sourcing Using Sampling; http://statacumen. com/sisus/) recently developed by E. B. Erhardt (University of New Mexico), which allows the inclusion of more prey items than ISOSOURCE. These models assume that isotopic values of all prey items are significantly different from each other and that an individual seal can consume all possible prey items.

To determine which prey items were available to seals in each area, we consulted the literature (Jemison 2001, Mathews 2002, Arimitsu et al. 2003, Robards et al. 2003) as well as the data on prey remains generated by the present study. We used isotopic values of prey reported by Blundell et al. (2002) as well as other studies (Table 2; Hobson \& Welch 1992, Hobson et al. 1997, Kline 1999, Lawson \& Hobson 2000, Takai et al. 2000,

Table 2. Stable isotope values for prey used in ISOSOURCE (Phillips \& Gregg 2003) and SISUS (E. B. Erhardt, University of New Mexico) to determine the proportions of different prey items in the diet of harbor seals. Prey with overlapping isotopic values were combined in the analyses. SE: standard error, n: number of specimens

\begin{tabular}{|c|c|c|c|c|c|c|c|c|}
\hline Prey & Scientific name & Habitat & $\delta^{13} \mathrm{C}$ & SE & $\delta^{15} \mathrm{~N}$ & $\mathrm{SE}$ & $\mathrm{n}$ & Source \\
\hline Capelin & Mallotus villosus & pelagic & -22.7 & 0.4 & 11.9 & 0.4 & 19 & Blundell et al. (2002) \\
\hline Cod & Gadus macrocephalus & intertidal/demersal & -17.5 & 0.1 & 12.1 & 0.2 & 6 & Blundell et al. (2002) \\
\hline Eulachon & Thaleichthys pacificus & pelagic & -18.4 & 0.1 & 14.0 & 0.2 & 20 & Kurle (2002) \\
\hline Flounder & $\begin{array}{l}\text { Glyptocephalus zachirus } \\
\text { Hippoglossoides elassodon } \\
\text { Paralichthys olivaceus }\end{array}$ & intertidal/demersal & -14.0 & 0.4 & 13.2 & 0.7 & 6 & Watanabe et al. (2006) \\
\hline Greenling & Hexagrammos decagrammus & intertidal/demersal & -17.5 & 0.09 & 14.5 & 0.09 & 61 & Blundell et al. (2002) \\
\hline Herring & Clupea pallasi ${ }^{\mathrm{a}}$ & pelagic & -20.2 & 0.2 & 12.5 & 0.2 & 15 & Blundell et al. (2002) \\
\hline Pollock & Theragra chalcogramma & intertidal/demersal & -17.2 & 0.02 & 14.7 & 0.02 & 10 & Present study \\
\hline Rockfish & Sebastes sp. & intertidal/demersal & -14.6 & 0.5 & 16.3 & 0.7 & 2 & Blundell et al. (2002) \\
\hline \multirow[t]{2}{*}{ Salmon } & Oncorhynchus sp. adult ${ }^{\mathrm{a}}$ & pelagic & -20.1 & 0.2 & 12.6 & 0.2 & 43 & Blundell et al. (2002) \\
\hline & Oncorhynchus sp. juvenile ${ }^{b}$ & pelagic & -19.8 & 0.4 & 11.3 & 0.3 & 10 & Blundell et al. (2002) \\
\hline Sandlance & Ammodytes hexapterus ${ }^{\mathrm{b}}$ & pelagic & -19.5 & 0.06 & 11.1 & 0.08 & 22 & Blundell et al. (2002) \\
\hline Sculpin & $\begin{array}{l}\text { Oligocottus maculosus } \\
\text { Icelinus borealis }\end{array}$ & intertidal/demersal & -17.1 & 0.2 & 15.1 & 0.2 & 12 & Blundell et al. (2002) \\
\hline Squid & Ommastrephes bartrami & pelagic & -18.5 & 0.4 & 11.6 & 1.9 & 49 & Takai et al. (2000) \\
\hline
\end{tabular}


Kurle 2002, Sherwood \& Rose 2005, Watanabe et al. 2006), and in the case of pollock Thegra chalcogramma we produced our own values. Whole pollock, caught for a sea lion study in PWS (D. Rosen pers. comm.), were initially homogenized using a blender and then prepared for stable isotope analyses using the method described above for blood samples. We compared published isotopic values for the same prey among studies, and where discrepancies in time and space occurred we selected the values produced closest to our sampling locations and times. We used consumer-diet discrimination values published by Lesage et al. (2001) and Hobson et al. (1996). Discrimination values for blood were $1.8 \pm 0.4$ (SE) for $\delta^{13} \mathrm{C}$ and $1.8 \pm 0.6$ for $\delta^{15} \mathrm{~N}$. Hair discrimination values were $2.3 \pm 0.05$ for $\delta^{13} \mathrm{C}$ and $2.3 \pm 0.4$ for $\delta^{15} \mathrm{~N}$. To ensure that seal values were included within the mixing space (Phillips \& Gregg 2003), we accounted for the variance associated with the discrimination factors and seal isotopic values.

\section{RESULTS}

Overall richness of prey remains was similar when corrected for the number of feces analyzed from terrestrial haul-outs in GB (21 items in 55 scats; 0.382) and PWS (16 items in 43 scats; 0.372; Table 3). Capelin, eelpout, gunnels, hake, shanny, snailfish, as well as polychaetes, were unique to seal diets in GB, whereas eulachon, mackerel, and ronquil appeared only in the diet of seals from PWS (Table 3). Prey richness of females in GB (17 items in 24 scats or $0.708 ; 90 \%$ confidence interval 0.523 to 0.854 ) was slightly higher than that of males in both areas (GB: 0.516 [0.352 to 0.676$]$; PWS: 0.550 [0.347 to 0.741]), and of females in PWS (0.522 [0.336 to 0.704]; Table 3). Diversity of prey for female seals in GB was higher $\left(H^{\prime}=11.743\right.$ in 24 scats $)$ than that of males in GB $\left(H^{\prime}=10.933\right.$ in 31 scats $)$ and males in PWS $\left(H^{\prime}=\right.$ 7.352 in 20 scats). Prey diversity in the diets of all

Table 3. Prevalence of different prey items in feces of male and female harbor seals from terrestrial haul-outs in Prince William Sound, PWS (2004 to 2005) and Glacier Bay, GB (2004 to 2006), corrected for digestion of hard parts. Correction factors were determined by prey digestibility (Harvey 1989, Tollit et al. 1997). n: number of seal feces examined. AV: adjusted value. Note that GB seals consumed a wider variety of prey species. -: this item not found in feces of animals in that category

\begin{tabular}{|c|c|c|c|c|c|c|c|c|c|c|}
\hline \multirow{3}{*}{ Prey } & \multirow{3}{*}{ Scientific name } & \multirow{3}{*}{$\begin{array}{l}\text { Correction } \\
\text { factor }\end{array}$} & \multirow{2}{*}{\multicolumn{4}{|c|}{$\begin{array}{cc}\text { Males } & \text { GB } \\
(\mathrm{n}=31) & \text { Females } \\
(\mathrm{n}=24)\end{array}$}} & \multicolumn{4}{|c|}{ _ PWS } \\
\hline & & & & & & & $\begin{array}{r}\text { Ma } \\
\text { (n = }\end{array}$ & & $\begin{array}{c}\text { Fem } \\
\text { (n = }\end{array}$ & $\begin{array}{l}\text { ales } \\
23)\end{array}$ \\
\hline & & & Count & AV & Count & AV & Count & AV & Count & AV \\
\hline Capelin & Mallotus villosus & 2.9 & 3 & 8.2 & 3 & 8.2 & - & - & - & - \\
\hline Cod (Pacific) & Gadus macrocephalus & 1.2 & 3 & 3.6 & - & - & 1 & 1.2 & - & - \\
\hline Eelpout (Wattled) & Lycodes palearis & 1.7 & - & - & 1 & 1.7 & - & - & - & - \\
\hline Eulachon & Thaleichthys pacificus & 2.9 & _- & _- & _- & - & 2 & 5.8 & 2 & 5.8 \\
\hline Flatfish & & 1.3 & - & - & 1 & 1.3 & - & - & - & - \\
\hline Flounder (Arrowtooth) & Atheresthes stomias & 1.3 & 4 & 5.2 & 2 & 2.6 & 2 & 2.6 & 1 & 1.3 \\
\hline Greenling & Hexagrammos sp. & 1.6 & 1 & 1.6 & - & - & - & - & - & - \\
\hline Greenling (Rock) & Hexagrammos lagocephalus & 1.6 & - & - & - & - & 1 & 1.6 & - & - \\
\hline Gunnel & Pholididae sp. & 1.7 & 1 & 1.7 & - & - & - & - & - & - \\
\hline Hake & Merluccius productus & 1.4 & 1 & 1.4 & 2 & 2.8 & - & - & - & - \\
\hline Halibut & Hippoglossus stenolepis & 1.3 & - & - & - & - & 1 & 1.3 & - & - \\
\hline Herring & Clupea pallasi & 3.1 & 3 & 9.3 & 4 & 12.4 & 4 & 12.4 & 12 & 37.2 \\
\hline Irish lord & Hemilepidotus sp. & 2.1 & 2 & 4.2 & 1 & 2.1 & - & - & - & - \\
\hline Irish lord (Red) & Hemilepidotus hemilepidotus & 2.1 & - & - & 1 & 2.1 & - & - & - & - \\
\hline Mackerel (Atka) & Pleurogrammus monopterygius & us 1.6 & - & - & - & - & - & - & 1 & 1.6 \\
\hline Pollock & Theragra chalcogramma & 1.4 & 15 & 21 & 13 & 18.2 & 15 & 21 & 15 & 21 \\
\hline Polychaete & & 1 & 2 & 2 & 2 & 2 & - & - & - & - \\
\hline Rockfish & Sebastes sp. & 2.1 & 1 & 2.1 & 2 & 4.2 & 3 & 6.3 & 9 & 18.9 \\
\hline Ronquil (Northern) & Ronquilus jordani & 1.7 & - & - & - & - & - & - & 1 & 1.7 \\
\hline Salmon & Oncorhynchus sp. & 1.6 & 1 & 1.6 & 4 & 6.4 & 2 & 3.2 & - & - \\
\hline Sandlance & Ammodytes hexapterus & 1.7 & 2 & 3.4 & 3 & 5.1 & - & - & 1 & 1.7 \\
\hline Sculpin (Great type) & Myoxocephalus sp. & 2.1 & 6 & 12.6 & - & - & - & - & - & - \\
\hline Sculpin (Ribbed) & Triglops pingelli & 2.1 & - & - & - & - & - & - & 2 & 4.2 \\
\hline Shanny (Daubed) & Lumpenus maculatus & 1.7 & - & - & 1 & 1.7 & - & - & - & - \\
\hline Snailfish & Liparidinae sp. & 1.6 & - & - & 1 & 1.6 & - & - & - & - \\
\hline Sole (Dover) & Microstomus pacificus & 1.3 & - & - & - & - & 2 & 2.6 & 1 & 1.3 \\
\hline Sole (Rex) & Glyptocephalus zachirus & 1.3 & - & - & - & - & 3 & 3.9 & 2 & 2.6 \\
\hline Sole (Sand) & Psettichthys melanostictus & 1.3 & 3 & 3.9 & 1 & 1.3 & - & - & - & - \\
\hline Squid/Octopus & & 2.3 & 1 & 2.3 & 2 & 4.6 & - & - & 2 & 2.3 \\
\hline
\end{tabular}




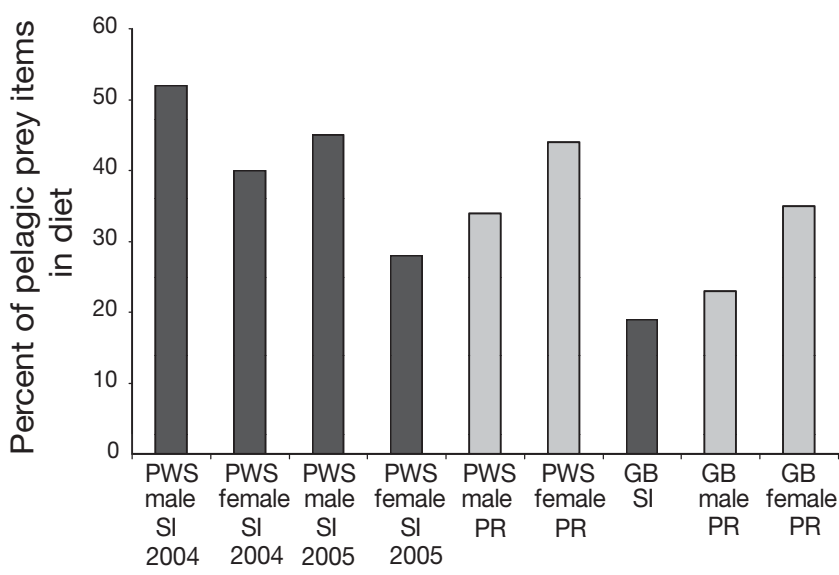

Fig. 2. Percent of pelagic fishes in the diet of harbor seals Phoca vitulina richardsi in Prince William Sound (PWS) and Glacier Bay (GB) as determined from analyses of prey remains (PR) in fecal samples and hair stable isotope (SI) analyses. Data were derived from Tables $2 \& 5$ by combining the percentages of all pelagic fish types. For PWS, SI data are presented separately for 2004 and 2005 because isotopic values were different between years. No such difference occured in GB these groups was higher than in females in PWS $\left(H^{\prime}=6.118\right.$ in 23 scats). The most prevalent prey item of both males and females in GB was pollock, followed by sculpin, herring, flatfish, salmon, and sandlance (Table 3). The most prevalent fish in diets of males in PWS was pollock, followed by herring, rockfish, and eulachon (Table 3). Females in PWS consumed more herring, with pollock, rockfish, and eulachon comprising the remaining majority of their diet (Table 3). Most importantly, the overall analysis of prey remains showed that seals in PWS consumed a higher proportion of pelagic fishes than seals in GB (Fig. 2).

Values of stable isotopes in blood were significantly different between GB and PWS, with seals in GB generally exhibiting lower values of $\delta^{15} \mathrm{~N}$ (MANOVA $\mathrm{p}<0.001, \delta^{13} \mathrm{C} \mathrm{p}<0.001, \delta^{15} \mathrm{~N} \mathrm{p}<0.0001$; Fig. 3). Blood results, however, do not provide a good direct comparison between areas, as they reflect different seasonal periods (PWS $=$ summer vs. GB = spring and fall). While isotopic values were similar in all years in $G B$, we detected a year effect in PWS $\left(p<0.001, \delta^{13} C\right.$

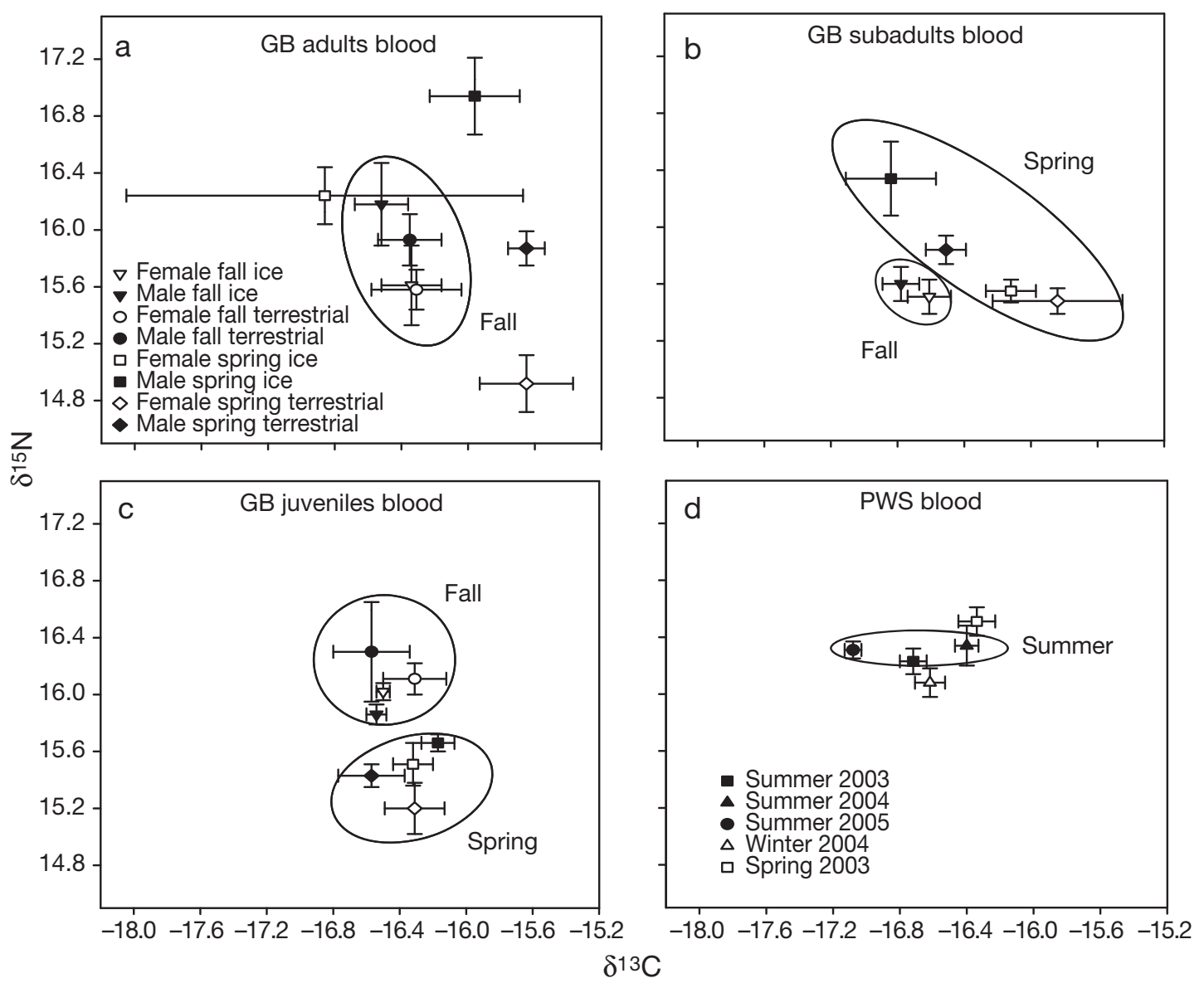

Fig. 3. Phoca vitulina richardsi. Isotopic values (mean \pm SE) of harbor seal blood in Glacier Bay (GB) from 2004 to 2006 and Prince William Sound (PWS) from 2003 to 2005. Significant sexual segregation in isotopic signatures occurs only for adults in GB and among years in PWS 


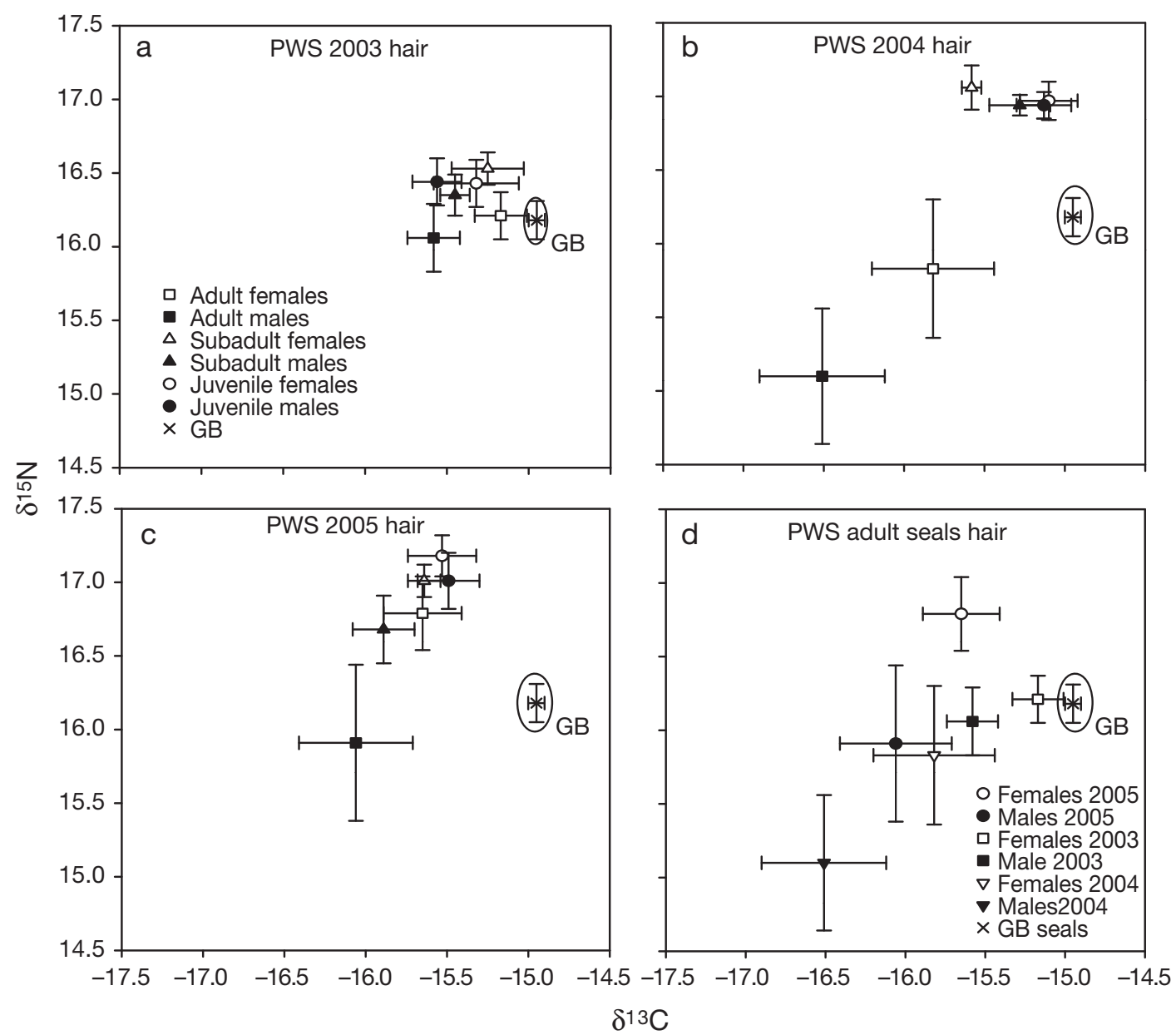

Fig. 4. Phoca vitulina richardsi. Isotopic values (mean \pm SE) of harbor seal hair collected in Glacier Bay (GB) from 2004 to 2006 and Prince William Sound (PWS) from 2003 to 2005. No significant differences among the sexes or age class were observed in GB during this time of year, although such differences were apparent in PWS

$\mathrm{p}<0.0001, \delta^{15} \mathrm{~N} \mathrm{p}<0.0001$; Fig. 3d) mainly through changes in values of $\delta^{13} \mathrm{C}$. As expected, based on seasonal variation in prey availability, blood isotopic values of seals in both areas changed with season $(\mathrm{p}=$

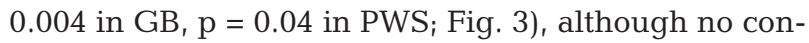
sistent seasonal pattern was found among age or sex classes. In GB, however, age ( $p=0.05)$, sex $(p<0.001)$, and habitat type (ice vs. terrestrial, $p=0.002$ ) all affected isotopic signatures in blood, although the difference in sex was non-existent for juveniles $(<1 \mathrm{yr}$; Fig. 3c). Adult females were more depleted in $\delta^{15} \mathrm{~N}$ than males during spring at terrestrial sites (Fig. 3a). During fall, sub-adults were more depleted in both $\delta^{13} \mathrm{C}$ and $\delta^{15} \mathrm{~N}$ than during other seasons (Fig. 3b), with the $\delta^{13} \mathrm{C}$ depletion indicating a diet containing more pelagic fishes. Juveniles were more enriched in $\delta^{15} \mathrm{~N}$ during fall than in spring (Fig. 3c). For PWS, no differences in blood isotopic values were found among age groups or between the sexes. Animals were, however, more enriched in $\delta^{15} \mathrm{~N}$ during winter and more depleted in $\delta^{15} \mathrm{~N}$ during spring, compared to summer (Fig. 3d).

Hair samples provided a more direct comparison of the diets of harbor seals in GB and PWS, because hair growth occurs in the same season in both areas. We found no significant differences in isotopic signatures among years, age classes, sex, or habitats for seals in GB (MANOVA $p>0.05$; Fig. 4). The diet of seals in GB, however, appeared to be different than the diet of seals in PWS $\left(\mathrm{p}<0.001, \delta^{13} \mathrm{C} \mathrm{p}<0.0001, \delta^{15} \mathrm{~N} \mathrm{p}<0.0001\right.$; Fig. 4), with GB seals having more enriched $\delta^{13} \mathrm{C}$ values. Seals in PWS differed in diet by year $(p<0.001)$, age, $(p<0.001)$, and sex $(p=0.006)$. Interannual and sexual differences in diet were most apparent in PWS adults (Fig. 4d). Adult males appeared to be eating prey with a significantly lower $\delta^{13} \mathrm{C}$ and $\delta^{15} \mathrm{~N}$ than females each year (Fig. 4d), indicating a diet containing more pelagic fish. Juvenile and sub-adult seals consumed similar diets, which differed from that of adults each year (Fig. 4). 
Table 4. Percentage (mean \pm SD) of various prey items in diet of harbor seals from Glacier Bay (GB) and Prince William Sound (PWS) as determined from blood samples using the program SISUS (E. B. Erhardt, University of New Mexico). The most prevalent prey items for each study group are in bold

\begin{tabular}{|c|c|c|c|c|c|c|c|c|c|c|c|c|c|}
\hline \multirow{4}{*}{ Prey } & \multirow{2}{*}{\multicolumn{3}{|c|}{ Summer PWS - }} & \multirow{4}{*}{$\begin{array}{l}\text { Spring } \\
2003\end{array}$} & \multirow{4}{*}{$\begin{array}{l}\text { Winter } \\
2004\end{array}$} & \multirow{2}{*}{\multicolumn{4}{|c|}{- GB }} & \multicolumn{4}{|c|}{3} \\
\hline & & & & & & & & & & & $-\mathrm{Fc}_{\mathrm{c}}$ & all & \\
\hline & \multirow{2}{*}{2003} & \multirow{2}{*}{2004} & \multirow[t]{2}{*}{2005} & & & \multicolumn{2}{|c|}{ Ice } & \multicolumn{2}{|c|}{ Terrestrial } & \multicolumn{2}{|c|}{ Ice } & \multicolumn{2}{|c|}{ Terrestrial } \\
\hline & & & & & & Males & Females & Males & Females & Males & Females & Males & Females \\
\hline Capelin & $28 \pm 0$ & $26 \pm 5$ & $38 \pm 1$ & $26 \pm 4$ & $27 \pm 6$ & $7 \pm 5$ & $36 \pm 4$ & $5 \pm 4$ & $5 \pm 4$ & $26 \pm 0$ & $11 \pm 6$ & $17 \pm 5$ & $11 \pm 6$ \\
\hline Cod & 0 & $1 \pm 1$ & 0 & $1 \pm 1$ & $2 \pm 2$ & $3 \pm 2$ & 0 & $6 \pm 4$ & $14 \pm 11$ & 0 & $4 \pm 3$ & $2 \pm 1$ & $4 \pm 4$ \\
\hline Eulachon & 0 & $9 \pm 8$ & $1 \pm 1$ & $5 \pm 5$ & $12 \pm 11$ & $12 \pm 10$ & $4 \pm 4$ & $10 \pm 8$ & $7 \pm 6$ & 0 & $13 \pm 12$ & $11 \pm 10$ & $13 \pm 11$ \\
\hline Flounder & 0 & $1 \pm 1$ & 0 & 0 & $2 \pm 1$ & $2 \pm 2$ & 0 & $5 \pm 3$ & $18 \pm 7$ & 0 & $3 \pm 2$ & 0 & $3 \pm 2$ \\
\hline Greenling & $62 \pm 0$ & $9 \pm 9$ & $1 \pm 1$ & $7 \pm 10$ & $11 \pm 10$ & $13 \pm 12$ & $6 \pm 8$ & $12 \pm 11$ & $7 \pm 6$ & 0 & $12 \pm 11$ & $10 \pm 9$ & $12 \pm 11$ \\
\hline Pollock & 0 & $9 \pm 8$ & $1 \pm 1$ & $5 \pm 4$ & $10 \pm 9$ & $13 \pm 12$ & $4 \pm 4$ & $14 \pm 11$ & $7 \pm 6$ & 0 & $12 \pm 10$ & $11 \pm 9$ & $12 \pm 10$ \\
\hline Rockfish & 0 & $1 \pm 6$ & $2 \pm 2$ & $8 \pm 8$ & $9 \pm 7$ & $15 \pm 10$ & $7 \pm 7$ & $16 \pm 9$ & $6 \pm 5$ & $10 \pm 0$ & $9 \pm 7$ & $13 \pm 10$ & $9 \pm 7$ \\
\hline Salmon/herring ${ }^{\mathrm{a}}$ & 0 & $4 \pm 4$ & 0 & $2 \pm 2$ & $7 \pm 6$ & $7 \pm 6$ & $2 \pm 2$ & $7 \pm 6$ & $7 \pm 6$ & 0 & $10 \pm 8$ & $5 \pm 4$ & $10 \pm 8$ \\
\hline $\begin{array}{l}\text { Salmon/sandlance }{ }^{\mathrm{a}} \\
\text { (juvenile) }\end{array}$ & 0 & $1 \pm 1$ & 0 & $1 \pm 1$ & $2 \pm 2$ & $3 \pm 3$ & 0 & $5 \pm 4$ & $9 \pm 7$ & 0 & $5 \pm 4$ & $2 \pm 2$ & $5 \pm 4$ \\
\hline Sculpin & $10 \pm 0$ & $26 \pm 13$ & $56 \pm 2$ & $44 \pm 11$ & $16 \pm 11$ & $22 \pm 15$ & $40 \pm 9$ & $15 \pm 12$ & $7 \pm 6$ & $64 \pm 0$ & $14 \pm 11$ & $26 \pm 14$ & $14 \pm 10$ \\
\hline Squid & 0 & $1 \pm 1$ & 0 & $1 \pm 1$ & $2 \pm 2$ & $3 \pm 2$ & 0 & $5 \pm 4$ & $12 \pm 9$ & 0 & $4 \pm 3$ & $2 \pm 1$ & $4 \pm 4$ \\
\hline
\end{tabular}

Relative contribution of diet items, as determined from isotope values of blood samples, differed between areas (Table 4). Samples from PWS suggest that capelin and sculpin were the major diet items of seals during spring and early summer. During winter, the diet of seals in PWS appears more varied with pollock, eulachon, and greenling joining capelin and sculpin as the major diet items (Table 4).

The most important prey items in GB varied with time of year and sex of the seal (Table 4, Fig. 2). Females found in the terrestrial habitat during spring appeared to forage evenly across all possible prey types, while males found in the glacial fjord habitat relied heavily on sculpin with a small contribution of capelin and rockfish to their diet (Table 4). The relative contribution of specific prey items for male and female seals caught in the glacial fjord changed seasonally, but the direction of this dietary shift was reversed for these 2 groups. For example, pollock composed $13 \%$ of the diet of males in spring and less than $1 \%$ in fall, whereas females assimilated about $4 \%$ of nutrients from pollock in spring and $12 \%$ in fall (Table 4 ).

Isotope levels in hair differed from those in blood, likely reflecting the different seasons these samples represent (hair - summer, blood - spring/early summer; Tables 4 \& 5). In GB during the summer, intertidal/demersal species such as rockfish, sculpin, and pollock, comprised a much greater proportion of seal diets. The diet of seals in PWS appeared to vary greatly from year to year during the summer, depending on the sex of the animal (Table 5). Nonetheless, similar to the results from prey remains in feces, the diet of seals in PWS during the summer of all sampling years contained a larger portion of pelagic fatty fishes than the diet of seals in GB (Fig. 2).

\section{DISCUSSION}

The combination of stable isotope and prey remains analyses suggests that, during summer, seals in GB (especially males) fed to a larger extent on intertidal/ demersal fishes than their conspecifics in PWS. Compared to their summer diets, seals in GB exhibited more diverse diets in spring and fall, which included relatively more pelagic fishes (e.g. capelin, eulachon, and herring). In summer, seals in GB switched to feed more uniformly on species with a lower fat content, such as rockfish and sculpin (Iverson et al. 2002), and their diets included low-quality prey such as gunnels, hake, shanny, snailfish, and polychaetes. Finally, seals in GB generally exhibited higher sexual dietary segregation than those in PWS. Together, these observations are consistent with our expectations of diet if foraging seals in GB are exposed to heightened interspecific competition and higher risk of predation, forcing them to forage on lower quality prey in habitat that reduces exposure to potential predators.

\section{Validity of analyses and methodology}

Although analyses of prey remains may yield biased estimates of diet, because feces contain only a snapshot in time of the diet for a particular seal and differential digestion rates may cause over- or underrepresentation of particular prey items (Murie \& Lavigne 1986, Harvey 1989, Tollit et al. 1997), we believe that our conclusions are valid. First, we used correction factors from the literature to account for digestibility. Second, our prey remains data are generally similar to those reported by other studies (Jemison 
Table 5. Percentage (mean $\pm \mathrm{SD}$ ) of harbor seal diet represented by various prey items for Glacier Bay (GB) and Prince William Sound (PWS) as determined from hair samples using the program SISUS (E. B. Erhardt, University of New Mexico). The most prevalent prey items for each study group are in bold

\begin{tabular}{|c|c|c|c|c|c|c|c|}
\hline \multirow[b]{2}{*}{ Prey } & \multicolumn{2}{|c|}{2003} & \multicolumn{2}{|c|}{$\begin{array}{l}\text { PWS } \\
2004 \\
\end{array}$} & \multicolumn{2}{|c|}{2005} & \multirow[t]{2}{*}{ GB } \\
\hline & males & $\overline{\text { females }}$ & male & $\overline{\text { females }}$ & males & $\overline{\text { females }}$ & \\
\hline Capelin & $7 \pm 5$ & $5 \pm 4$ & $16 \pm 8$ & $9 \pm 6$ & $14 \pm 7$ & $25 \pm 12$ & $3 \pm 2$ \\
\hline Cod & $6 \pm 5$ & $7 \pm 6$ & $9 \pm 8$ & $7 \pm 5$ & $5 \pm 4$ & 0 & $6 \pm 5$ \\
\hline Eulachon & $12 \pm 10$ & $10 \pm 8$ & $8 \pm 7$ & $12 \pm 10$ & $13 \pm 11$ & $2 \pm 3$ & $7 \pm 6$ \\
\hline Flounder & $5 \pm 3$ & $6 \pm 4$ & $6 \pm 5$ & $5 \pm 4$ & $3 \pm 3$ & 0 & $7 \pm 4$ \\
\hline Greenling & $13 \pm 11$ & $12 \pm 10$ & $7 \pm 6$ & $11 \pm 10$ & $12 \pm 10$ & $2 \pm 3$ & $9 \pm 8$ \\
\hline Pollock & $12 \pm 10$ & $13 \pm 11$ & $6 \pm 5$ & $11 \pm 9$ & $11 \pm 9$ & $2 \pm 3$ & $10 \pm 9$ \\
\hline Rockfish & $10 \pm 7$ & $15 \pm 8$ & $4 \pm 3$ & $8 \pm 6$ & $8 \pm 6$ & $26 \pm 24$ & $31 \pm 9$ \\
\hline Salmon/herring ${ }^{\mathrm{a}}$ & $9 \pm 7$ & $7 \pm 6$ & $14 \pm 11$ & $11 \pm 8$ & $12 \pm 9$ & $1 \pm 2$ & $5 \pm 4$ \\
\hline $\begin{array}{l}\text { Salmon/sandlance }{ }^{\mathrm{a}} \\
\text { (juvenile) }\end{array}$ & $6 \pm 5$ & $6 \pm 5$ & $14 \pm 10$ & $8 \pm 6$ & $6 \pm 4$ & 0 & $4 \pm 4$ \\
\hline Sculpin & $13 \pm 10$ & $13 \pm 11$ & $06 \pm 5$ & $11 \pm 9$ & $12 \pm 10$ & $40 \pm 29$ & $11 \pm 10$ \\
\hline Squid & $6 \pm 5$ & $6 \pm 5$ & $11 \pm 9$ & $7 \pm 6$ & $5 \pm 4$ & 0 & $5 \pm 4$ \\
\hline
\end{tabular}

2001, Mathews 2002). Finally, our results from prey remains analyses are supported by those produced by our stable isotope analyses, validating our conclusions, especially for GB. This support is important as stable isotope analyses represent the incorporation of nutrients from prey into tissue over longer time periods (Martinez del Rio \& Wolf 2005).

One deficiency of stable isotope analysis is the reliance on mixing models to determine the relative contribution of prey items to the diet (Phillips \& Gregg 2003). Assumptions associated with such models can lead to biases in diet estimation. To alleviate these problems, we grouped prey items with similar isotopic signatures and introduced only those prey items to the models that are common for harbor seal diets in our study areas. Despite relatively small differences, results from these mixing models suggest that these isotopic values are biologically meaningful. In addition, the isotopic signatures were within the range of those reported in previous studies (Hobson et al. 1997, Hirons et al. 2001). Thus, despite the individual shortfalls of each method, their combination yielded comparable and interpretable results. Indeed, other studies have successfully used the combination of fecal and stable isotope analyses to estimate the diet of pygmy raccoons Procyon pygmaeus (McFadden et al. 2006) and long-nosed bandicoots Parameles nasuto (Thums et al. 2005).

\section{Differences in dietary sexual segregation between areas}

Sexual segregation in feeding habits of seals in both GB and PWS was more evident in adults. We observed little difference in the diets of juvenile male and female seals, with a slight increase in divergence in subadults. Similar observations were made for New Zealand and Australian fur seals foraging under high interspecific competition (Page et al. 2005). Adult harbor seals, however, showed clear divergence in diet during specific times of the year in both areas. In PWS, sexual segregation was only evident during the late summer (hair samples) but not in winter or spring (blood samples). This sexual dietary segregation during post-pupping and breeding in PWS is similar to that reported by Breed et al. (2006) for grey seals Halichoerus grypus. During pupping and weaning, female grey seals foraged close to haul-out sites, which resulted in small home ranges, while males were observed feeding across a wide geographic area and exhibited large home ranges (Breed et al. 2006). Breed et al. (2006) proposed that such behavioral differences were related to differential timing and magnitude of reproductive expenditure. Indeed, our data on carbon and nitrogen stable isotope ratios in the hair of seals in PWS and the associated evaluation of the relative dietary contributions indicate that males were feeding to a larger extent on pelagic fishes, while females foraged more on intertidal/subtidal fishes, perhaps as a result of opportunistic foraging closer to their haul-outs during and after the pupping season. This trend of females foraging more intertidally than males during pupping periods has also been observed in other marine species such as coastal river otters Lontra canadensis (Blundell et al. 2002), and reproductive expenditure was proposed as the driving force for sexual segregation in ungulates (Main et al. 1996).

In contrast, sexual segregation of diet in GB was most prevalent in fecal samples collected throughout the sampling period as well as in blood samples during 
the spring and fall captures, with segregation most prevalent in seals from the ice. Sexual dietary segregation in GB was not detected in late summer, when all animals uniformly switched to feed on fishes with lowenergy density (Anthony et al. 2000, Iverson et al. 2002). At this time of year, foraging by seals may be limited because of the energetic constraints caused by molting (Boily 1995). Indeed, harbor seals spend up to $60 \%$ of their time hauled out during molt, compared to only 25 to $32 \%$ of their time spent on land between fall and early spring (Frost et al. 2001). If the observed narrowing of diet for seals in GB was solely due to seals conserving energy through opportunistic feeding upon intertidal/demersal fishes close to their haul-outs, we would expect to see similar patterns in PWS. That no such pattern occurred in PWS suggests that other factors may be affecting the diet of seals in GB.

\section{Effects of increased competition and predation risk}

Mathews \& Pendleton (2006) suggested that increased competition may be leading to the population declines seen in GB, but lacked data with which to investigate that hypothesis. Similarly, Bowen et al. (2003) cited competition with the increasing grey seal population as contributing to harbor seal declines on Sable Island off the coast of Nova Scotia, Canada. In GB, numbers of whales have increased (humpbacks by $55 \%$ and killer whales by $>1 \%$ ), with the highest presence occurring at the onset of summer (Mathews \& Pendleton 2006, Neilson \& Gabriele 2006, J. Womble pers. comm.). Numbers of sea lions, which have also increased in recent years (from 135 to 791 ind., an increase of $485 \%$ ), remained high throughout the summer (Womble et al. 2005, Mathews \& Pendleton 2006). Using the daily energy requirements for both seals and humpback whales and a dietary overlap estimate of $50 \%$, Mathews \& Pendleton (2006) calculated that one whale consumes the food needed to support 90 harbor seals. When considering the increase in the number of whales in GB, it appears that whales alone now consume the amount of prey that previously supported 2070 seals. In addition, humpback whales have lately been observed to feed directly offshore of seal haulouts, where no whale activity had been observed in the past (Neilson \& Gabriele 2006), which could displace seals from these feeding sites. Steller sea lions have been shown to have almost $100 \%$ dietary overlap with harbor seals (Pitcher 1981) and consume the same amount of prey per body mass (Innes et al. 1987). On average, however, a male Steller sea lion is 6.8 times larger than a male harbor seal, and a female sea lion is 3.67 times larger than a female seal. When considering the increase in sea lion populations in GB, their con- sumption of prey is equal to the amount previously consumed by 2407 to 4460 seals. Thus, the combined increase in sea lions and whales accounts for a decrease in prey availability that is equal to the diet of 4477 to 6350 harbor seals. It is currently estimated that the harbor seal population in GB declined by ca. 3650 seals (Mathews \& Pendleton 2006), which is slightly lower than the decline expected based on competition. Indeed, our results are consistent with the effects expected from an increase in the threat of predation and competition in GB. During summer, seal diets were more restricted than in spring and fall and included a higher proportion of lower quality items, as indicated by fecal analysis. Under this increased competition, molting seals are likely forced to either forage within areas that are closer to haul-outs to reduce predation risk or to feed on prey items that are less accessible or of less interest to competitors.

Interestingly, blood samples from seals captured on the ice had lower $\delta^{13} \mathrm{C}$ ratios during spring and fall than seals captured at terrestrial haul-outs, indicating that they fed on pelagic fishes to a larger extent. Telemetry data show that some of the seals captured on the ice traveled over $85 \mathrm{~km}$ from Johns Hopkins Inlet to forage outside of GB (Womble et al. 2007, ADF\&G and NMFS unpubl. data). This movement is likely restricted during molt and when risk of predation increases, leading to the lack of differences in isotopic signatures of hair tissues between ice and terrestrial seals. Seals captured at terrestrial haul-outs likely do not make wide-ranging foraging trips because they do not have to travel long distances to find alternative shallow intertidal areas for foraging when pelagic forage fish are not present or are inaccessible (www.absc.usgs.gov/research/seabird_ foragefish/maps/index.html, 2007).

\section{CONCLUSIONS}

Multiple lines of evidence indicate that seals in GB experience heightened competition and risk of predation that alter their diets. The diet of GB seals is more diverse and of higher quality in spring and fall when fewer potential competitors and/or predators are present, but seals switch to a lower quality diet when competitor/predator numbers increase in the summer. This conclusion is further supported by the fact that we observed no differences between years in diets of seals in GB, whereas inter-annual variation was pronounced in seal diet in PWS. The inter-annual variation in PWS likely follows yearly changes of prey species in seal foraging areas (Gibson et al. 1993, Brown \& Pierce 1998, Robards et al. 2003). That no such inter-annual change in diet occurs in GB suggests that productivity in the system is relatively constant, but that availability 
and accessibility of prey change seasonally with the arrival of whales. Unfortunately, data on fish abundance and distribution during the present study was not available for both areas.

Predation on harbor seals by killer whales and sea lions in GB has been documented (Mathews \& Pendleton 2006, Womble et al. 2007). Although predation may be contributing to the observed seal declines, it is unlikely that predation rates are high enough to be the only driving force behind this phenomenon. Observations of predation events in GB remain low $(1$ in $1680 \mathrm{~h}$ of observation during the $4 \mathrm{yr}$ of the present study), and captured seals do not frequently exhibit injuries that may result from failed predation events as seen in other harbor seal populations where declines have been linked directly to predation (Bowen et al. 2003). This anecdotal evidence, combined with our results of dietary changes that coincided with increased competition and predation risk for seals, suggest that seal declines may be a result of emigration from GB rather than mortality.

In terrestrial systems, several studies documented shifts in diet and habitat use by smaller, less competitive predators as a result of interference competition from top predators (Major \& Sherburne 1987, Cypher \& Spencer 1998, Durant 1998, Kitchen et al. 1999, Smith et al. 2003). For example, cheetahs Acynonix jubatus on the Serengeti plains use areas of lower prey density to avoid competition with lions Panthera leo and hyenas Crocuta crocuta in both time and space (Durant 1998). Red foxes Vulpes vulpes avoid competition with coyotes by spatial avoidance (Major \& Sherburne 1987), and swift foxes Vulpes velox and kit foxes Vulpes macrotis mutica exhibit dietary shifts when they co-occur with coyotes (Cypher \& Spencer 1998, Kitchen et al. 1999). The most notable example followed the reintroduction of wolves Canus lupus to Yellowstone National Park (YNP) in 1996. After wolves were established in YNP, a drastic decline of $50 \%$ occurred in the overall coyote Canus lantrans population, with up to $90 \%$ declines noted within the core areas used by wolf packs. Much like Steller sea lions and harbor seals, wolves and coyotes have high dietary overlap and use similar habitat types. In addition, coyotes are occasionally killed by wolves (Smith et al. 2003). It is unclear, however, what portion of coyote declines in YNP can be attributed directly to mortality from wolf encounters versus emigration to avoid competition and risk of predation.

Using genetic tools, Herreman (2007) estimated that 63 seals per generation migrate from GB to PWS, and only 22 animals per generation migrated in the opposite direction. Herreman (2007) proposed that migration rates from GB to other areas in southeast Alaska may be even higher. These migration rates, coupled with our dietary analyses, suggest that seal numbers are likely not declining due to direct predation, but rather that seals are responding to heightened competition and predation risk from whales and sea lions by emigrating out of GB. Thus, it appears that the recent increase in top predators that simultaneously compete for the same food base, as well as prey on seals, caused bottom-up dietary changes in harbor seals that induced a large portion of the population to emigrate to other areas of southeast and south-central Alaska.

Acknowledgements. This research was conducted under authorization of NMFS Scientific Research Permit Nos. 3581585 and 358-1787 and was funded by annual grants to the Alaska Department of Fish and Game for harbor seal investigations in Alaska, allocated by the US Congress and administered through the Alaska Region of the NMFS of the National Oceanic and Atmospheric Administration. We thank the National Park Service for the authorization to conduct research in Glacier Bay National Park and for providing logistical support. Many individuals and organizations were involved in the capture and collection efforts including ADF\&G: S. Karpovich, S. Wolfe, D. Crowley, J. Wells, J. Prewitt, R. Naylor, T. Peltier, C. Clark; Alaska SeaLife Center: S. Conlon, A. Hoover-Miller, P. Tuomi, M. Gray, S. Atkinson; the MV 'Babkin' and 'Alexandra' crews: B., A., and K. von Wichman, L. Bassett, N. Robinson; MV 'Steller' crew: D. Foley, A. Byrnes, S. Damron; NOAA: D. Withrow, J. Jansen; veterinarians: J. Bailey, E. Wolf, M. Haulena, R. Berngartt, N. Caulkett, K. Savage, L. Bailey; NPS: S. Gende, M. Hazen, J. Womble; WDF\&W: B. Murphy, T. Cyrus, S. Jeffries; and others: L. Clark, J. Wyatt, and C. Shanley. Thanks to K. Ott for support and input, S Albeke for producing Fig. 1, and D. Doak, T. Thurow, and D. B. McDonald for their reviews. All experiments and handling of wildlife were in compliance with current laws and regulations of the USA.

\section{LITERATURE CITED}

Angliss RP, Outlaw RB (2007) Alaska marine mammal stock assessments 2006. NOAA Technical Memorandum NMFSAFSC-168. US Department of Commerce National Oceanic and Atmospheric Administration, National Marine Fisheries Service, Alaska Fisheries Science Center, Juneau, AK

Anthony JA, Roby DD, Turco KR (2000) Lipid content and energy density of forage fishes from the northern Gulf of Alaska. J Exp Mar Biol Ecol 248:53-78

Arimitsu ML, Litzow MA, Piatt JF, Robards MD, Abookine AA, Drew GS (2003) Inventory of marine and estuarine fishes in southeast and central Alaska National Parks. USGS Biological Resource Division, Alaska Science Center, Anchorage

Ben-David M, Flynn RW, Schell DM (1997) Annual and seasonal changes in diets of martens: evidence from stable isotope analysis. Oecologia 111:280-291

Bleich VC, Bowyer RT, Wehausen JD (1997) Sexual segregation in mountain sheep: resources or predation? Wildlife Monographs, Bethesda, MD

> Blundell GM, Pendleton GW (2008) Estimating age of harbor seals (Phoca vitulina) with incisor teeth and morphometric measurements. Mar Mamm Sci 24:577-590

Blundell GM, Ben-David M, Bowyer TR (2002) Sociality in 
river otters: cooperative foraging or reproductive strategies? Behav Ecol 13:134-141

Boily P (1995) Theoretical heat-flux in water and habitat selection of phocid seals and beluga whales during the annual molt. J Theor Biol 172:235-244

Boutin-Ganache I, Raposo M, Raymond M, Deschepper F (2001) M13-tailed primers improve the readability and usability of microsatellite analyses performed with two different allele-sizing methods. Biotechniques 31:24-26, 28

Boveng PL, Bengtson JL, Withrow DE, Cesarone JC, Simpkins MA, Frost KJ, Burns JJ (2003) The abundance of harbor seals in the Gulf of Alaska. Mar Mamm Sci 19:111-127

Bowen WD, Ellis SL, Iverson SJ, Boness DJ (2003) Maternal and newborn life history traits during periods of contrasting population trends: implications for explaining the decline of harbour seals, Phoca vitulina, on Sable Island. J Zool (Lond) 261:155-163

Breed GA, Bowen WD, McMillan JI, Leonard ML (2006) Sexual segregation of seasonal foraging habitats in a non-migratory marine mammal. Proc R Soc Lond B Biol Sci 273:2319-2326

Brown EG, Pierce GJ (1998) Monthly variation in the diet of harbor seals in inshore waters along the southeast Shetland (UK) coastline. Mar Ecol Prog Ser 167:275-289

Catton T (1995) Land reborn: a history of administration and visitor use in Glacier Bay National Park and Preserve, available at www.nps.gov/archive/glba/adhi/adhi.htm

> Corti P, Shackleton DM (2002) Relationship between predation risk factors and sexual segregation in Dall's sheep (Ovis dalli dalli). Can J Zool 80:2108-2117

Cypher BL, Spencer KA (1998) Competitive interactions between coyotes and San Joaquin Kit Foxes. J Mammal 79:204-214

> Daniel RG, Jemison LA, Pendleton GW, Crowley SM (2003) Molting phenology of harbor seals on Tugidak Island, Alaska. Mar Mamm Sci 19:128-140

> Durant SM (1998) Competition refuges and coexistence: an example from Serengeti carnivores. J Anim Ecol 67:370-386

Estes JA, Demaster DP, Doak DF, William TM, Brownell RL Jr (eds) (2006) Whales, whaling and ocean ecosystems. University of California Press, Berkeley, CA

Francis RC, Hare SR, Hollowed AB, Wooster WS (1998) Review: effects of interdecadal climate variability on the oceanic ecosystems of the NE Pacific. Fish Oceanogr 7:1-21

Fritz LW, Hinckley S (2005) A critical review of the regime shift-'junk food'-nutritional stress hypothesis for the decline of the western stock of Steller sea lion. Mar Mamm Sci 21:476-518

Frost KJ, Lowry LF, Ver Hoef JM (1999) Monitoring the trend of harbor seals in Prince William Sound Alaska, after the Exxon Valdez oil spill. Mar Mamm Sci 15:494-506

Frost KJ, Simpkins MA, Loury LF (2001) Diving behavior of subadults and adult harbor seals in Prince William Sound, Alaska. Mar Mamm Sci 17:813-834

Gelatt TS, Trites AW, Hastings K, Jemison K, Pitcher K, O'Corry-Crow G (2007) Population trends, diet, genetics, and observations of Steller sea lions in Glacier Bay National Park. In: Piatt JF, Gende SM (eds) Proc 4th Glacier Bay Sci Symp, US Geological Survey Scientific Investigations Report 2007-5047, p 145-149

Gibson RN, Ansell AD, Robb L (1993) Seasonal and annual variations in abundance and species composition of fish and macrocrustacean communities on a Scottish sandy beach. Mar Ecol Prog Ser 98:89-105

Harvey JT (1989) Assessment of errors associated with harbour seal (Phoca vitulina) faecal sampling. J Zool (Lond) 219:101-111
Herreman JK (2007) Geneflow and diet for two declining harbor seal (Phoca vitulina) populations off the coast of Alaska. Ms thesis, University of Wyoming, Laramie

Hilderbrand GV, Farley SD, Robbins CT, Hanley TA, Titus K, Servheen C (1996) Use of stable isotopes to determine diets of living and extinct bears. Can J Zool 74:2080-2088

Hirons AC, Schell DM, Finney BP (2001) Temporal records of $\delta^{13} \mathrm{C}$ and $\delta^{15} \mathrm{~N}$ in North Pacific pinnipeds: inferences regarding environmental change and diet. Oecologia 129: 591-601

> Hobson KA, Welch HE (1992) Determination of trophic relationships within a high Arctic marine food web using $\delta^{13} \mathrm{C}$ and $\delta^{15} \mathrm{~N}$ analysis. Mar Ecol Prog Ser 84:9-18

> Hobson KA, Schell DM, Renoir D, Noteworthy E (1996) Stable carbon and nitrogen isotopic fractionation between diet and tissues of captive seals: implications for dietary reconstructions involving marine mammals. Can J Fish Aquat Sci 53:528-533

Hobson KA, Seas JL, Merrick RL, Piatt JF (1997) Investigating trophic relationships of pinnipeds in Alaska and Washington using stable isotope ratios of nitrogen and carbon. Mar Mamm Sci 13:114-132

> Holbrook SJ, Schmitt RT (1988) Effects of predation risk on foraging behavior: mechanisms altering patch choice. J Exp Mar Biol Ecol 121:151-163

Hooge PN, Hooge ER (2002) Fjord oceanographic processes in Glacier Bay, Alaska. Technical Report prepared for the National Park Service, Glacier Bay National Park, USGS-Alaska Science Center, Anchorage, AK

> Ibrahim AA, Huntingford FA (1989) Laboratory and field studies of the effect of predation risk on foraging in three spined sticklebacks (Gasterosteus aculeatus). Behaviour 109:46-57

Innes S, Lavigne DM, Earle WM, Kovaks KM (1987) Feeding rates of seals and whales. J Anim Ecol 56:115-130

> Iverson SJ, Frost KJ, Lang SLC (2002) Fat content and fatty acid composition of forage fish and invertebrates in Prince William Sound Alaska: factors contributing to among and within species variability. Mar Ecol Prog Ser 241:161-181

Jemison LA (2001) Summary of harbor seal diet data collected in Alaska from 1990-1999. In: Harbor seal investigations in Alaska Annual Report NOAA. Alaska Department of Fish and Game, Division of Wildlife Conservation, Anchorage, p 314-322

Jemison LA, Pendleton GW, Wilson CA, Small RJ (2006) Long-term trends in harbor seal numbers at Tugidak Island and Nanvak Bay, Alaska. Mar Mamm Sci 22:339-360

Jenkins D, Walker JGK, McCowan D (1979) Analyses of otter (Lutra lutra) faeces from Deeside, NE Scotland. J Zool 187:235-244

Johnson RA, Wichern DW (1988) Applied multivariate statistical analysis. Prentice-Hall, Englewood Cliffs, NJ

Kitchen AM, Geese EM, Schanster ER (1999) Resource partitioning between coyotes and swift foxes: space, time and diet. Can J Zool 77:1645-1656

Kline TC Jr (1999) Temporal and spatial variability of ${ }^{13} \mathrm{C} /{ }^{12} \mathrm{C}$ and ${ }^{15} \mathrm{~N} /{ }^{14} \mathrm{~N}$ in pelagic biota of Prince William Sound Alaska. Can J Fish Aquat Sci 56:94-117

Kurle CM (2002) Stable isotope ratios of blood components from captive northern fur seals (Callorhinus ursinus) and their diet: applications for studying the foraging ecology of wild otariids. Can J Zool 80:902-909

> Lawson JW, Hobson KA (2000) Diet of Harp seals (Pagophilus groenlandicus) in nearshore northeast Newfoundland: inferences form stable-carbon $\left({ }^{13} \mathrm{C}\right)$ and nitrogen $\left({ }^{15} \mathrm{~N}\right)$ isotope analyses. Mar Mamm Sci 16:578-591

> Lesage V, Hammil MO, Kovacs KM (2001) Marine mammals 
and the community structure of the Estuary and Gulf of St Lawrence, Canada: evidence from stable isotope analysis. Mar Ecol Prog Ser 210:203-221

Lydersen C, Kovacs KM (2005) Growth and population parameters of the world's northernmost harbour seals Phoca vitulina residing in Svalbard, Norway. Polar Biol 28:156-163

Main MB, Weckerly FW, Bleich VC (1996) Sexual segregation in ungulates: new directions for research. J Mammal 77: 449-461

Major JT, Sherburne JA (1987) Interspecific relationships of coyotes, bobcats, and red foxes in Western Maine. J Wildl Manag 51:606-616

Martinez del Rio C, Wolf BO (2005) Mass-balance models for animal isotopic ecology. In: Starck JM, Wang T (eds) Physiological and ecological adaptations to feeding in vertebrates. Science Publishers, Enfield, NH, p 141-173

Mathews EA (2002) Diet of harbor seals at a glacial fjord and a terrestrial haulout in Glacier Bay 1996-2001. Report to Glacier Bay National Park and Preserve, Resource Management Division, Gustavus, AK

Mathews EA, Pendleton GW (2006) Declines in harbor seal (Phoca vitulina) numbers in Glacier Bay National Park Alaska, 1992-2002. Mar Mamm Sci 22:167-189

Matkin DR, Straley JM, Gabriele CM (2007) Killer whale feeding ecology and non-predatory interactions with other marine mammals in the Glacier Bay region of Alaska. In: Piatt JF, Gende SM (eds) Proc 4th Glacier Bay Sci Symp, US Geological Survey Scientific Investigations Report 2007-5047, p 155-158

> McFadden WKW, Sambrotto RN, Medellin RA, Gompper ME (2006) Feeding habits of endangered pygmy raccoons (Procyon pygmaeus) based on stable isotope and fecal analyses. J Mammal 87:501-509

Murie DJ, Lavigne DM (1986) Interpretation of otoliths in stomach content analyses of phocid seals: quantifying fish consumption. Can J Zool 64:1152-1157

Neilson JL, Gabriele CM (2006) Results of humpback whale population monitoring in Glacier Bay and adjacent waters: 2006. National Park Service Report, Glacier Bay National Park \& Preserve, Gustavus, AK

> Page B, McKenzie J, Goldsworthy SD (2005) Dietary resource partitioning among sympatric New Zealand and Australian fur seals. Mar Ecol Prog Ser 293:283-302

Phillips DL, Gregg JW (2003) Source partitioning using stable isotopes: coping with too many sources. Oecologia 136: 261-269

Pitcher KW (1981) Prey of the Steller sea lion, Eumetopias jubatus, in the gulf of Alaska. Fish Bull 79:467-472

Power ME (1992) Top-down and bottom-up forces in food webs: do plants have primacy? Ecology 73:733-746

Reed JZ, Tollit DJ, Thompson PM, Amos W (1997) Molecular scatology: the use of molecular genetic analysis to assign species, sex and individual identity to seal faeces. Mol Ecol 6:225-234

Richard KR, McCarrey SW, Wright JM (1994) DNA sequence from the SRY gene of the sperm whale (Physeter macrocephalus) for use in molecular sexing. Can J Zool 72:873-877

Robards M, Drew G, Piatt J, Anson JM and others (2003) Ecology of selected marine communities in Glacier Bay: zooplankton, foragefish, seabirds, and marine mammals. USGS, Alaska Science Center Report for the National Park Service, Anchorage, AK

Rosen DAS, Trites AW (2000) Pollock and the decline of Steller sea lions: testing the junk-food hypothesis. Can J Zool 78:1243-1250

> Sherwood GD, Rose GA (2005) Stable isotope analysis of some representative fish and invertebrates of the Newfoundland and Labrador continental shelf food web.
Estuar Coast Shelf Sci 63:537-549

Smith DW, Peterson RO, Houston DB (2003) Yellowstone after wolves. BioScience 53:330-340

Springer AM, Estes JA, Van Vliet GB, Williams TM and others (2003) Sequential megafaunal collapse in the North Pacific Ocean: an ongoing legacy of industrial whaling? Proc Natl Acad Sci USA 100:12223-12228

Stewart KM, Bowyer RT, Kie JG, Dick BL, Ben-David M (2003) Niche partitioning among mule deer, elk and cattle: Do stable isotopes reflect dietary niche? Ecoscience 10: 297-302

Stiling P (1999) Ecology theories and applications. Third edn. Prentice Hall, Upper Saddle River, NJ

Takai N, Onaka S, Ikeda Y, Yatsu A, Kidokoro H, Sakamoto W (2000) Geographical variations in carbon and nitrogen stable isotope ratios in squid. J Mar Biol Assoc UK 80: $675-684$

Thums M, Klaassen M, Hume ID (2005) Seasonal changes in the diet of the long nosed bandicoot (Perameles nasuta) assessed by analysis of faecal scats and of stable isotopes in blood. Aust J Zool 53:87-93

Tollit DJ, Steward MJ, Thompson PM, Pierce GJ, Santos MB, Hughes S (1997) Species and size differences in the digestion of otoliths and beaks: implications for estimates of pinniped diet composition. Can J Fish Aquat Sci 54: 105-119

Trites AW, Donnelly CP (2003) The decline of Steller sea lions Eumetopias jubatus in Alaska: a review of the nutritional stress hypothesis. Mammal Rev 33:3-28

Trites AW, Christensen V, Pauly D (1997) Competition between fisheries and marine mammals for prey and primary production in the Pacific Ocean. J Northwest Atl Fish Sci 22:173-187

Trites AW, Deecke VB, Gregr EJ, Ford JKB, Olesiuk PF (2007a) Killer whales, whaling and sequential megafaunal collapse in the North Pacific: a comparative analysis of the dynamics of marine mammals in Alaska and British Columbia following commercial whaling. Mar Mamm Sci 23:751-765

> Trites AW, Miller AJ, Maschner HDG, Alexander MA and others (2007b) Bottom-up forcing and the decline of Steller sea lions (Eumetopias jubatus) in Alaska: assessing the ocean climate. Fish Oceanogr 16:46-67

Wade PR, Burnkanov VN, Dahlheim ME, Friday NA and others (2007) Killer whales and marine mammal trends in the North Pacific: a re-examination of evidence for sequential megafauna collapse and the prey-switching hypothesis. Mar Mamm Sci 23:766-802

Watanabe $\mathrm{S}$, Isshiki $\mathrm{T}$, Kudo $\mathrm{T}$, Yamada A, Katayama $\mathrm{S}$, Fukuda M (2006) Using stable isotope ratios as a tracer of feeding adaptation in released Japanese flounder Paralichthys olivaceus. J Fish Biol 68:1192-1205

Werner EE, Hall DJ (1988) Ontogenetic habitat shifts in bluegill: the foraging rate-predation risk trade-off. Ecology 69: 1352-1366

Werner EE, Gilliam JF, Hall DJ, Mittlebach GG (1983) An experimental test of the effects of predation risk on habitat use in fish. Ecology 64:1540-1548

Womble JN, Wilson MF, Sigler MF, Kelly BP, VanBlaricom GR (2005) Distribution of Steller sea lions Eumetopias jubatus in relation to spring-spawning fish in SE Alaska. Mar Ecol Prog Ser 294:271-282

Womble JN, Gende SM, Blundell GB (2007) Harbor seal foraging ecology investigations in Glacier Bay National Park: annual report 2006. US National Park Service, Coastal Program

Zar JH (1999) Biostatistical analysis, 2nd edn. Prentice-Hall, Englewood Cliffs, NJ 